\title{
DOI 10.31558/2307-2318.2019.4.2
}

\section{УДК 339.138}

Захарова О.В., д.е.н., проф., Черкаський державний технологічний університет Проданова Л.В., д.е.н., доц., Черкаський державний технологічний університет Клівак О.О., магістрат, Черкаський державний технологічний університет

\section{ІННОВАЦІЙНІ МЕТОДИ МАРКЕТИНГОВОГО МЕНЕДЖМЕНТУ НА ПРИКЛАДІ МОДЕЛІ БІЗНЕСУ INDITЕХ}

Систематизовано основні наукові підходи щодо розуміння сутності та змісту маркетингового менеджменту, зокрема як філософії управління, концепції, системи, процесу, функції, мистецтва та науки. Досвід успішного застосування методів маркетингового менеджменту представлено моделлю бізнесу корпорації INDITEX, яка побудована на основі маркетингово-орієнтованого управлінського підходу, що ставить споживачів у фокусі організації та спрямований на здійснення кожним підрозділом організації свого внеску в належне обслуговування клієнтів. Визначено основні елементи та фактори успішної бізнес-моделі підприємства, що грунтується на засадах маркетингового менеджменту: чутливість виробництва і логістики до кон'юнктури ринку; швидка позитивна реакція на зміни та висока готовність до них; постійно високий рівень іміджу та якості товарів і послуг; активна орієнтація на клієнта; контроль та пріоритетність власного виробництва та каналів продажів; якісна та ефективна багаторівнева система зворотного зв'язку; постійні інновації; активна участь у вирішення актуальних соціальних та екологічних проблем. Окреслено позитиви та переваги сучасних бізнес-моделей за рахунок запровадження технологій цифрового маркетингу та електронної комерції, а також омніканальності - інтегрування всіх каналів маркетингової та торговельної діяльності.

Ключові слова: маркетинговий менеджмент, модель бізнесу, торговельне підприємство, торгівля в роздріб одягом та взуттям, електронна комерція, цифровий маркетинг.

Табл. -1 , Літ. -25 .

\section{Захарова О.В., Проданова Л.В., Кливак Е.О. ИННОВАЦИОННЫЕ МЕТОДЫ МАРКЕТИНГОВОГО МЕНЕДЖМЕНТА НА ПРИМЕРЕ МОДЕЛИ БИЗНЕСА INDITЕХ}

Систематизированы основные научные подходы к пониманию сущности и содержания маркетингового менеджмента, в частности как философии управления, концепции, системы, процесса, функции, искусства и науки. Опыт успешного применения методов маркетингового менеджмента представлено моделью бизнеса корпорации INDITEX, построенной на основе маркетингово-ориентированного управленческого подхода, который помещает потребителей в фокус организации и направлен на осуществление каждым подразделением организации своего вклада в надлежащее обслуживание клиентов. Определены основные элементы и факторы успешной бизнес-модели предприятия, основанной на принципах маркетингового менеджмента: чувствительность производства и логистики к конъюнктуре рынка; быстрая положительная реакция на изменения и высокая готовность к ним; постоянно высокий уровень имиджа и качества товаров и услуг; активная ориентация на клиента; контроль и приоритетность собственного производства и каналов продаж; качественная и эффективная многоуровневая система обратной связи; постоянные инновации; активное участие в решении актуальных социальных и экологических проблем. 
Определены преимущества современных бизнес-моделей за счет применения технологий цифрового маркетинга и электронной коммерции, а также омниканальности - интегрирования всех каналов маркетинговой и торговой деятельности.

Ключевые слова: маркетинговый менеджмент, модель бизнеса, торговое предприятие, торговля в розницу одеждой и обувью, электронная коммерция, цифровой маркетинг

\section{Zakharova O., Prodanova L., Klivak O. INNOVATIVE MARKETING MANAGEMENT'S METHODS ON THE EXAMPLE INDITEX`S BUSINES 'S MODEL}

The basic scientific approaches to understanding the essence and content of marketing management are systematized, in particular as management philosophy, concept, system, process, function, art and science. Successful application of marketing management techniques is represented by the business model of INDITEX Corporation, which is built on the basis of a marketing-oriented management approach that puts consumers in the focus of the organization and aims to make each unit of the organization contribute to the proper customer service. The basic elements and factors of successful business model of the enterprise are determined, based on the principles of marketing management: sensitivity of production and logistics to market conditions; rapid positive response to and readiness for change; constantly high level of image and quality of goods and services; active customer orientation; control and priority of own production and sales channels; a high-quality and efficient multi-level feedback system; continuous innovation; active participation in solving current social and environmental problems. Positives and advantages of modern business models at the expense of introduction of technologies of digital marketing and e-commerce, and also omni-channel - integration of all channels of marketing and trading activity are outlined.

Key words: marketing management, business model, trading company, fashion retail, digital marketing, electronic commerce

Постановка проблеми та їі зв'язок з важливими науковими чи практичними завданнями. Розглядаючи сучасні моделі бізнесу, слід виділити суттєву різницю між моделлю, в якій маркетинг виступає лише однією з функцій управління, і новою, де маркетинг впливає на всі управлінські рішення. Окрім того, маркетинг відокремився в окрему ланку в системі управління організацією, а тому став об' єктом організаційного управління. Результатом таких процесів є інтеграція маркетингу і менеджменту, для позначення чого з'являється поняття «маркетинговий менеджмент» («маркетингменеджмент», «маркет-менеджмент»). На практиці це сприяло формуванню якісно нового підходу до управління виробництвом і збутом товарів та послуг на засадах маркетингового менеджменту. В сучасних умовах стрімкого розвитку науки, техніки i технологій, посилення ринкової конкуренції та ринкової орієнтації підприємств, успіху може досягти тільки те підприємство (та відповідно його організація), яке постійно шукає нові способи адаптації до безперервно мінливих ринкових умов свого функціонування та розвитку, що, у свою чергу, потребує творчих підходів щодо застосування новітніх ефективних методів управління. У зв'язку з цим дослідження інноваційних методів маркетингового менеджменту, які застосовують в своїх бізнесмоделях провідні компанії світу, набуває особливої актуальності. 
Аналіз останніх досліджень і публікацій 3 проблеми, що розглядається. Дослідженню проблем маркетингового менеджменту загалом та використання його методів в сучасних бізнес-моделях ритейлу зокрема присвячені роботи відомих закордонних і вітчизняних науковців.

Вважається, що уведення в науковий обіг поняття «маркетинговий менеджмент» («marketing management»), а також його подальше поширення в теорії та практиці управління тісно пов'язано з Г. Армстронгом [1], П. Друкером [2], Ф. Котлером [3], К. Келлером [3] та ін.

Сучасні українські науковці продовжують дослідження різноманітних аспектів маркетингового менеджменту: за висновком Л. Балабанової [4], В. Россохи [5], маркетинговий менеджмент слід розглядати в широкому та вузькому аспектах; на думку М. Белявцева, В. Воробйова [6] та О. Біловодської [7], маркетинговий менеджмент пов'язаний з ринковою діяльністю не лише на рівні окремого підприємства, а й на рівні відповідних ринків/територій і суспільства в цілому; на дослідженні впливу управління, яке грунтується на засобах маркетингу, а також на конкретизації процедур маркетингового менеджменту, які застосовуються в діяльності підприємств, зосереджують свою увагу I. Баланюк та О. Ткач [8]. Але, незважаючи на плідний доробок у зазначеному напрямі, проблема розвитку теоретичних підходів до визначення сутності маркетингового менеджменту та практичного застосування його методів в сучасних бізнес-моделях підприємств різних галузей та сфер економіки залишається актуальною і зумовлює необхідність проведення поглиблених досліджень.

Мета дослідження полягає в виявленні інноваційних методів маркетингового менеджменту на прикладі моделі бізнесу компанії INDITEX.

Виклад основного матеріалу. Наразі єдиного підходу до розуміння сутності та змісту маркетингового менеджменту в сучасній науковій літературі не існує. В таблиці 1 представлені різноманітні підходи до визначення сутності та змісту маркетингового менеджменту, які зустрічаються в сучасній науковій літературі. Результати аналізу підходів та визначень дають підстави для висновку, що поняття «маркетинговий менеджмент» в сучасній науковій літературі вживається у таких значеннях: філософія управління; концепція маркетингу; система методів управління організацією; складова частини системи управління; процес; функція; мистецтво та наука.

Слід погодитись 3 точкою зору тих дослідників, які вважають, що під маркетинговим менеджментом доцільно розуміти: 1) холістичну концепцію комплексного управління ринковою діяльністю організації (на принципах маркетингу), яка в умовах гострої конкуренції спирається на ринкову орієнтацію; 2) особливий спосіб мислення керівників організації та управлінців всіх рівнів - прийняття необхідних управлінських рішень з урахуванням вимог ринку, постійно висока здатність до змін цих вимог; 3) система методів управління організацією, що передбачає використання маркетингових підходів та інструментів під час вирішення максимально широкого кола завдань різних функціональних сфер менеджменту [6; 13].

Необхідно також погодитися 3 думкою науковців, які розглядають маркетинговий менеджмент як маркетингово-орієнтований підхід, що ставить споживачів у фокусі організації та спрямований на здійснення кожним підрозділом організації свого внеску в належне обслуговування клієнтів [5, с. $112 ; 13$, с. 743$]$. Кінцевий результат такого підходу - повне задоволення потреб споживачів. Саме такий підхід вже багато років поспіль ефективно використовує корпорація INDITEX у моделі своєї діяльності. 
Таблиця 1

Підходи до визначення сутності та змісту маркетингового менеджменту в сучасній науковій літературі

\begin{tabular}{|c|c|c|}
\hline Автори & $\begin{array}{c}\text { Авторські розуміння сутності та змісту } \\
\text { маркетингового менеджменту }\end{array}$ & $\begin{array}{c}\text { Акцентування } \\
\text { на відповідному } \\
\text { значенні }\end{array}$ \\
\hline $\begin{array}{l}\text { Американська } \\
\text { асоціація } \\
\text { маркетингу } \\
{[9 ; \text { цитується }} \\
\text { 3а } 10, \text { с. } 22] \\
\end{array}$ & $\begin{array}{l}\text { Маркетинг менеджмент - процес планування та } \\
\text { реалізації загальної концепції, політики ціноутворення, } \\
\text { просування та розподілу ідей, товарів і послуг, } \\
\text { спрямований на здійснення обмінів, які відповідають } \\
\text { як індивідуальним так й організаційним цілям }\end{array}$ & процес \\
\hline $\begin{array}{l}\text { Ф. Котлер } \\
{[10, \text { с. } 22-23]}\end{array}$ & $\begin{array}{l}\text { Маркетинг менеджмент - мистецтво і наука } \\
\text { застосування основоположних маркетингових } \\
\text { концепцій для вибору цільових ринків, залучення, } \\
\text { збереження і розширення кола нових споживачів } \\
\text { шляхом створення та надання високоякісних } \\
\text { споживчих цінностей та здійснення пов'язаних з ними } \\
\text { комунікацій }\end{array}$ & $\begin{array}{l}\text { мистецтво і } \\
\text { наука }\end{array}$ \\
\hline $\begin{array}{l}\text { Л. Балабанова } \\
\text { [4] }\end{array}$ & $\begin{array}{l}\text { Маркетинговий менеджмент - поняття більш широке, } \\
\text { ніж управління маркетингом. Якщо останне являє } \\
\text { собою одну із загальних функцій менеджменту, то } \\
\text { маркетинговий менеджмент - це управління всіма } \\
\text { функціями, всіма структурними підрозділами на основі } \\
\text { маркетингу }\end{array}$ & функція \\
\hline $\begin{array}{l}\text { М. Белявцев, } \\
\text { В. Воробйов } \\
{[6, \text { с. } 145]}\end{array}$ & $\begin{array}{l}\text { Маркетинговий менеджмент слід розглядати як } \\
\text { філософію управління організацією за допомогою } \\
\text { основ маркетингу, яка включає принципи, методи, } \\
\text { засоби, інструменти та форми управління маркетингом }\end{array}$ & $\begin{array}{l}\text { філософія } \\
\text { управління }\end{array}$ \\
\hline \begin{tabular}{|l} 
Д. Райко \\
{$[11$, с. 117$]$}
\end{tabular} & $\begin{array}{l}\text { Маркетингове управління (маркетинговий } \\
\text { менеджмент) - сучасна концепція маркетингу, } \\
\text { принципово новий підхід, перш за все, до } \\
\text { стратегічного управління організацією, що в умовах } \\
\text { гострої конкуренції спирається на ринкову орієнтацію }\end{array}$ & концепція \\
\hline $\begin{array}{l}\text { I. Липсиц } \\
{[12, \text { с. 69]. }}\end{array}$ & $\begin{array}{l}\text { Маркетинг-менеджмент - система методів управління } \\
\text { організацією, що передбачає використання } \\
\text { маркетингових підходів та інструментів під час } \\
\text { вирішення максимально широкого кола завдань різних } \\
\text { функціональних сфер менеджменту - від маркетингу } \\
\text { відносин до внутрішнього маркетингу та управління } \\
\text { ланцюгами поставок }\end{array}$ & $\begin{array}{l}\text { система методів } \\
\text { управління } \\
\text { організацією }\end{array}$ \\
\hline $\begin{array}{l}\text { С. Яроміч, } \\
\text { Т. Величко } \\
{[13, \text { с. } 741]}\end{array}$ & $\begin{array}{l}\text { Менеджмент формулює цілі, шукає ресурси, оцінює } \\
\text { результати, маркетинг слугує засобом досягнення } \\
\text { визначених цілей, а маркетинговий менеджмент постає } \\
\text { як складова частина системи управління у цілому }\end{array}$ & $\begin{array}{l}\text { складова } \\
\text { частина системи } \\
\text { управління }\end{array}$ \\
\hline
\end{tabular}

Засновником компанії INDITEX й відповідно іiі бізнес-моделі $є$ іспанський підприємець Амансіо Ортега Гаона (нар. 1936 р., наразі - мільярдер, член правління та головний акціонер INDITEX) [14]. Історія INDITEX починається в 1963 р. 3 невеличкої швейної майстерні в іспанському містечку Ла-Корунья. Корпорація INDITEX сьогодні $\epsilon$ вертикально інтегрованою, має у складі дослідницькі і проектно-конструкторські підрозділи, виробничі потужності, розподільчі центри, транспортний парк та магазини 
(близько 7500 магазинів працңюють в 96 краӥнах світу). INDITEX управляє 8 брендами роздрібної торгівлі одягом, взуттям та аксесуарами (fashion retail), флагманом яких $\epsilon$ Zara, цільовою аудиторією бренду якої є жінки середнього класу. Серед інших Pull\&Bear (повсякденний одяг для молоді), Massimo Dutti (одяг для клієнтів обох статей з рівнем доходу вище середнього), Bershka (одяг для тінейджерів), Stradivarius (одяг для молодих жінок), Oysho (білизна), Zara Home (домашні вироби - товари для дому) та Uterqüe (аксесуари) [15].

У списку найбільших публічних компаній світу Forbes Global 2000 за 2019 р. INDITEX зайняла 289-е місце, у тому числі 327-е місце за оборотом, 188-е - за чистим прибутком, 109-е - за чистими активами та 100-е за ринковою капіталізацією [16]. У списку компаній, що спеціалізуються на виготовленні та реалізації брендового одягу та взуття, INDITEX займає третє місце після Christian Dior (143-е місце) та Nike (280-е місце) [там само].

Сучасна бізнес-модель корпорації INDITEX формувалась під впливом декількох важливих чинників. Розглянемо їх докладніше. У 80-ті рр. ХХ ст. вперше з'явилося поняття «fast fashion» (з англ. - «швидка мода») і відповідна бізнес-модель, застосування якої сприяло значному розвитку європейської текстильної промисловості в період останніх 40 років. Засновником саме цієї бізнес-моделі вважається А. Ортега, який зміг задовольнити потребу покупців в «одязі з подіумів» [15]. Здійснював він це шляхом копіювання трендів і тенденцій високої моди в більш спрощеному дизайні з прийнятною якістю і за доступною ціною, скоротивши до 15 днів шлях від виробництва продукту до споживача, і доставляючи його в магазини двічі на тиждень. INDITEX, на відміну від конкурентів, не витрачала багато коштів на рекламу, натомість інвестувала у відкриття нових магазинів та жорстко керувалась своїм засновником.

За оцінками експертів у сфері бізнесу, успіх А. Ортега полягає в тому, що він свого часу відмовився від бізнес-моделі, якій впродовж десятиліть слідували всі модні будинки Європи, і замінив іiі на швидку і жорстку схему виробництва та товарообігу. Сам А. Ортега упевнений, що побудував свою імперію виходячи з двох основних принципів: «дайте клієнтам те, що вони хочуть, і будьте швидше, ніж всі інші» [14].

Вивчення ключових факторів успіху функціонування та розвитку корпорації INDITEX дозволяє виокремити такі особливості ії бізнес-моделі [17; 18]:

1) швидкість - виготовлення і постачання продукту на полиці магазинів швидше за конкурентів; створення такої моди, що підлягає постійному оновленню; вироблення саме тих товарів, яких покупці хочуть отримати вже сьогодні; першокласний імідж і торгові точки, розташовані в кращих місцях;

2) орієнтація на клієнта - покупець завжди знаходиться в центрі уваги: в період створення нових моделей, дизайну магазинів, оновлення логістичної системи тощо. Для цього в компанії уважно придивляються до того, що носять найчастіше, прислухаються до бажань покупців, блогерів і лідерів думок; виробляють лише те, що люди хочуть купувати;

3) контроль виробничої мережі - пріоритетним є власне виробництво. До 60\% продукту компанія виробляє в Іспанії, Португалії та Марокко, а решту (40\%) виготовляє із залученням аутсорсингових компаній (491 постачальник в Свропі, 759 - в Азії, 135 - в Африці, 160 - в інших країнах світу): зазвичай складні партії одягу шиють на власних фабриках, а прості - віддають на аутсорсинг (відносини за яким врегульовані кодексом ділової поведінки);

4) швидка логістика: логістичний центр в одному з головних розподільних центрів (м. Артейхо, Іспанія) побудований рівновіддалено від 14 великих фабрик. Така модель 
використовується й в інших десятьох розподільних центрах компанії, для доставки продукції застосовують різні види транспорту, в т.ч. авіаперевезення;

5) концепція зворотного зв'язку, добре налагоджений між магазинами, які електронними засобами пов'язані з штаб-квартирою компанії;

6) постійні інновації - виступають основою конкурентоспроможності;

7) активне залучення до вирішення соціальних та екологічних проблем як в окремих регіонах (базування і розміщення виробництва/вирощування сировини та магазинів) так і в планетарному масштабі.

INDITEX постійно залишає додаткові виробничі незавантажені потужності на своїх заводах, щоб реагувати на пік і несподіваний попит швидше за конкурентів. Виробництво та розподіл продуктів здійснюється невеликими партіями. Інвестиції в основний капітал збільшує гнучкість, а бренди набувають конкурентних переваг завдяки чіткому використанню інформації та технологій. Крім того, у магазинах INDITEX нові продукти представлено в обмеженій кількості. Така роздрібна концепція залежить від регулярності створення й швидкості поповнення партій нових товарів та дозволяє знизити поточні витрати й скоротити залишки товарів. Наприклад, залишки товарів у магазинах Zara становлять менше 10\% (для порівняння: в середньому в промисловості цей показник становить від 17-20\%) [19]. INDITEX активно використовує такі канали та засоби інформування покупців як: Інтернет (має власний Інтернет-сайт, власний YouTube-channel, а також користується рекламними послугами відомих блогерів); випускає щоквартальний журнал «IN», в якому міститься вся необхідна (для споживача) інформація про бренди компанії, виготовляє та поширює брошури та буклети, рекламує нові колекції та окремі моделі в глянцевих журналах (зокрема «Cosmopolitan», «Voque», «Glamour»). Слід також зазначити, що доволі часто INDITEX замість витрачання коштів на рекламу, спрямовує їх на дизайн вітрин своїх численних магазинів (вітрини оновлюють кожні три тижні, де широко представлені ключові моделі колекцій) [17].

Головні інновації компанії INDITEX впродовж останніх років: застосування технологій цифрового маркетингу та електронної комерції. а також перехід до впровадження моделі омніканальності (шляхом інтегрування всіх каналів, які задіяно для маркетингової та торговельної діяльності [20, с. 96-97]).

Специфікою цифрового маркетингу, як відомо, $є$ використання сучасних інформаційних ресурсів та технологій (зокрема цифрових, електронних ресурсів та технологій, Інтернет-каналу) для проведення маркетингових досліджень, реалізації товарної і цінової політики, доведення продукції (інформації про продукт) до споживача та стимулювання збуту з метою максимального задоволення потреб споживачів через інноваційну організацію матеріального та інформаційного обміну. Потенціал цифрового маркетингу для підприємців при використанні його інструментів та методів реалізується в можливостях знижувати маркетингові та виробничі витрати, здійснювати ефективні маркетингові дослідження, автоматизувати процеси інформування клієнтів, проводити аналіз ринку, підвищувати ефективність взаємодії покупця і продавця.

Електронна торгівля характеризується використанням широкого набору інтерактивних методів ведення торговельної діяльності (з реалізації товарів та послуг), де продавці і покупці взаємодіють не в процесі фізичного обміну чи контакту, а 3 використанням відповідних комунікацій та технологій обробки й передачі інформації (у тому числі цифрових, електронних ресурсів та технологій, Інтернет-каналу). Основні переваги електронної торгівлі (придбання товарів в інтерактивному режимі в порівнянні 3 традиційними покупками у звичайному магазині) [21, с. 66]: скорочення часу на відвідування магазину, можливість швидкого ознайомлення з товарами та послугами, що 
пропонують електронні магазини, а також економія на транспортних витратах з проїзду до місця знаходження стаціонарного магазину з відповідним асортиментом; спрощення процедури пошуку товару, яка дозволяє знайти аналогічний товар у різноманітних електронних магазинах, а також найбільш повно враховує індивідуальні вимоги та можливості цінового діапазону користувача; доступність електронних магазинів та можливість здійснювати покупки у зручний та вільний час; заощадження (економія) коштів від «прямої» купівлі товару у підприємства-виробника, тобто можливість «обійти» посередників; практично безмежні можливості (продавця) для розширення сегменту ринку (до світового рівня), результатом чого зазвичай є зниження цін на товари та послуги на традиційних ринках; економія часу та коштів при купівлі товарів і послуг, які можуть бути доставлені покупцю безпосередньо до дому чи в офіс; підвищений рівень післяпродажного обслуговування, що досягається завдяки інтерактивному спілкуванню з менеджерами та консультантами магазинів за допомогою спеціалізованих каналів зв'язку, використання електронної пошти та спеціалізованих програмних засобів.

Основним сучасним каналом цифрового маркетингу та електронної торгівлі вважається канал Інтернет. Переваги Інтернет як каналу маркетингу та торгівлі, порівно 3 іншими каналами [22, с. 121]: таргетинг - можливість демонстрації інформації чітко визначеній аудиторії; трекінг - можливість аналізу поведінки відвідувачів корпоративного сайту i вдосконалення сайту, продукту (маркетингу i торгівлі) відповідно до висновків такого аналізу; доступність (за принципом 24 години на добу, 7 днів на тиждень) і гнучкість (можливість почати, коригувати і перервати будь-яку маркетингову чи комерційну кампанію можна миттєво); інтерактивність - споживач може взаємодіяти 3 продавцем і з продуктом, вивчати його, інколи «скуштувати» або «приміряти» i, якщо товар влаштовує, придбати його; можливість розміщення великої кількості інформації; оперативність поширення і отримання інформації; порівняно низький рівень витрат (вартість реалізації заходів); можливість отримання більш пильної уваги споживача (користувача перед комп'ютером) - концентрації на деталях; можливість створення віртуальних спілок (on-line community), зокрема за інтересами, професією та ін., тобто цільової аудиторії.

Висновки. У підсумку слід зазначити, що розбудову ефективної бізнес-моделі INDITEX із використанням принципів та методів маркетингового менеджменту, на яких акцентовано увагу в проведеному дослідженні, успішно продовжено в 2019 р., підтвердженням чого є матеріали та інформація, представлені на офіційному сайті корпорації [23]. Зростання корпорації INDITEX впродовж січня-жовтня 2019 p. (в порівнянні з відповідним періодом 2018 р.), що вимірюється збільшенням сумарних об'ємів продажів (всіх брендів) - на 7,5\%, а чистого прибутку - на $12 \%$, досягнуто завдяки «ретельному відбору місць розміщення, торговельних площ, товарів та послуг найвищої якості, а також значним інвестиціям в технології та постійній турботі про запровадження найкращих процесів для забезпечення довгострокового стійкого зростання» [там само]. Зростання обумовлено також розвитком комплексної (омніканальної) платформи, що складається 3 фізичних та інтернет-магазинів та забезпечує повну комерційну інтеграцію й оптимальне управління товарними запасами. Наразі бренди компанії: розширили та оновили свої магазини в 96 країнах, в 66-ти з яких одночасно пропонують онлайн-продажі; утворюють глобальний інтернет-магазин, який загалом охоплює 200 країн світу. Керівництво компанії вважає, що в 2020 році INDITEX матиме платформу продажів, яка буде повністю інтегрованою, стійкою та цифровою. Ключовими характеристиками моделі визначено: якість, прозорість та відкритість, 
стійкість. Роботу моделі заплановано із застосуванням найкращих соціальних та екологічних практик [24; 25]. В умовах економічної кризи в Україні орієнтація на принципи впровадження та інноваційні методи маркетингового менеджменту розбудови бізнес-моделі INDITEX може дати поштовх для розвитку промислового сектору та сфери послуг.

\section{СПИСОК ВИКОРИСТАНИХ ДЖЕРЕЛ}

1. Армстронг М. Менеджмент: методы и приемы. Пер. с англ. изд. Киев: Знання-Прес, $2006.876 \mathrm{c}$.

2. Друкер П. Энциклопедия менеджмента. Под ред Т.А. Гуреш. Пер. с англ. О. Пелявского. Москва: Издательский дом «Вильяме», 2004. 432 с.

3. Котлер Ф., Келлер К.Л. Маркетинг Менеджмент. Экспресс-курс. Пер. с англ. под науч. ред. С. Жильцова. СПб.: Питер, 2012. 480 с.

4. Балабанова Л.В. Маркетинговий менеджмент. Київ: Знання, 2004. 354 с.

5. Россоха В.В. Маркетинговий менеджмент в системі управління підприємством. Агроінком. 2012. №10-12. С. 108-112.

6. Белявцев М.І. Маркетинговий менеджмент. За ред. М. Белявцева, В. Воробйова, В. Кузнєцова. Київ: Донецький нац. ун-т, 2006. 407 с.

7. Біловодська О.А. Маркетинговий менеджмент. Київ: Знання, 2010. 332 с.

8. Ткач О.В., Баланюк І.Ф., Копчак Ю.С., Баланюк С.І. Маркетинговий менеджмент у діяльності підприємств. Науковий вісник Ужгородського університету. Серія Економіка. 2016. Вип. 1(47). Т. 2. С. 291-296.

9. Peter D. Bennett, ed., Dictionary of Marketing Tenns, 2d ed. Chicago: American Marketing Association, 1995.

10. Котлер Ф. Маркетинг менеджмент. Экс пресс-курс. Пер. с англ. под ред. С. Божук. СПб.: Питер, 2006. 464 с.

11. Райко Д.В. Лебедєва Л.Е. Модель управління маркетингом у системі менеджменту промислового підприємства. Маркетинг і менеджмент інновацій. 2015. № 1. С. 107-123. 12. Маркетинг-менеджмент. Под ред. И.В. Липсица, О.К. Ойнер. Москва: Юрайт, 2016. $379 \mathrm{c}$.

13. Яроміч С.А., Величко Т.Г. Сутність поняття маркетингового менеджменту в науковому дискурсі. Економіка і суспільство. 2017. № 9. С. 740-745.

14. Эксклюзив: Амансио Ортега: Тайна за семью печалями. URL: http://www.goldmustang.ru/magazine/exclusive/2576.html.

15. Lee J. The model of fast fashion industry: a case survey of «Inditex». Актуальні проблеми економіки. 2016. № 11. С. 430-436.

16. Inditex on the Forbes 2000. URL : https://www.forbes.com/companies/inditex/\#15bbd9051e90.

17. Ukrainian Retail Assosiation. URL: https://rau.ua/uk/novyni/ujti-krasivo-5-sekretov-povedeniyu-feshn-biznesa-ot-osnovatelya-zara/.

18. Захарова О.В., Клівак О.О. Конкурентоспроможність підприємства на прикладі інноваційної бізнес-моделі «Indetex». Актуальні проблеми сучасної економіки та niдприємництва. Матеріали Всеукраїнської наукової конференції студентів та молодих науковців. Покровськ: ДонНТУ, 2018, 134 с. С. 41-44.

19. Włodzimierz Rudny Business model design and its importance in successful strategy - the case of Zara. Вісник соиіально-економічних досліджень. 2012. Вип. 3(1). С. 129-134.

20. Гліненко Л.К., Дайновський Ю.А. Стан і перспективи розвитку електронної торгівлі України. Маркетинг і менеджмент інноваџій. 2018. №1. С. 83-102. 
21. Хамула О.О. Завдання та проблеми розвитку сфери електронної торгівлі в Україні як середовища функціонування системи реалізації книжкової продукції. Наукові записки : наук.-техн. зб. Львів: УАД. 2015. №2 (51). С. 63-69.

22. Падерін I. Д., Романов О. В., Титовец Є. С. Розвиток інтернет-маркетингу на підприємствах малого та середнього бізнесу. Економічний вісник Донбасу. 2016. № 1(43). C. $120-124$.

23. Inditex's net sales climb $7.5 \%$ to $€ 19.8$ billion. URL : https://www.inditex.com/en/article?articleId=641861\&title=Inditex\%E2\%80\%99s+net +sales+climb+7.5\%25+to++\%E2\%82\%AC19.8+billion.

24. INDITEX. Our model. URL: https://www.inditex.com/en/how-we-do-business/our-model. 25. INDITEX. Annual report 2018. URL: https://www.inditex.com/en/home. 